\title{
A Three-Dimensional Conceptual Framework of Corporate Water Responsibility
}

\author{
Fabien Martinez ${ }^{1,2}$
}

\begin{abstract}
This article offers a conceptual framework that comprehensively describes essential aspects of corporate water responsibility. What heretofore has been essentially regarded as an issue to be tackled by governmental institutions, and therefore not perceived as an important component of the value that is created for the institutional and private owners of profit-driven companies, is explicitly treated here as a corporate responsibility. Bridging knowledge domains, I review major research works conducted by management, corporate sustainability, and (welfare) economics scholars and focusing on water management issues to unveil the conditions under which corporations are likely to manage, or to be challenged in managing, water in responsible/ sustainable ways. Three types of "tensions" that confront academics and managers alike are discussed: voluntary actions versus coercion, free riding versus cooperation, and economic versus corporate water responsibility motives. I propose a three-dimensional framework of corporate water responsibility for thinking through the managerial response patterns contemplated to address these tensions.
\end{abstract}

\section{Keywords}

water resources management, business sustainability, corporate water responsibility, integrative literature review

\section{Introduction: The Water Management Challenge}

Water management is widely recognised as a pressing issue to be resolved and a complex challenge that involves a multitude of actors. Evidence of overuse and degradation of water is widely available from credible sources such as the United Nations (UN) and Transparency International, both compelling and convincing. ${ }^{1}$ Prospects for the future are not promising, and the situation is aggravated by current predictions of climate change and its effect on water flows and scarcity, which will potentially transform the physical and human geography of the planet, affecting where and how we live our lives (Stern, 2008). ${ }^{2}$ Even in water-rich Canada, which has $9 \%$ of the world's freshwater, there are local water shortages and widespread contamination of both surface water and groundwater (Clarke, 2013). The problem of how water resources should be protected and preserved attracts a high level interest among international bodies (e.g., European Union, 2013;

\footnotetext{
'Vlerick Business School, Brussels, Belgium

${ }^{2}$ Academy of Business In Society, Brussels, Belgium
}

\section{Corresponding Author:}

Fabien Martinez, Academy of Business in Society, Avenue Moliere, 128, Ixelles, Brussels 1050, Belgium.

Email: fabien.martinez@abis-global.org 
OECD, 2012; World Business Council for Sustainable Development, 2013; Worldwide Fund for Nature, 2012), policy review agencies (or "think tanks"), policy makers, ${ }^{3}$ and welfare economists seeking to support the development of a comprehensive sustainability framework for managing water. Such a framework is currently lacking (or defective), partly because interests and perceptions about the urgency of the task ahead have differed widely among scholars, companies, and policy makers and water has not been dealt with as a primary focus of international discussions (Messerlin, 2011). The broad consensus that the planet is "facing a growing global water crisis" (Balali, Keulartz, \& Korthals, 2009; Clarke, 2013; Jones, 2010) should generate new theoretical and empirical studies seeking to improve our relations with the environment, and especially with water resources.

Improvements in the area of water management are necessary for at least two reasons. First, human (and especially industrial) activities play a part in creating water-related problems (Clarke, 2013; Jones, 2010). As we strive to find new sources of fossil fuels to sustain our living standards, the water footprint of human activities increases and so does the potential for polluting those resources, and as the demand for unseasonal produce in Western countries continues, drought causes widespread starvation in the countries that export them. ${ }^{4}$ Second, water provides a range of ecosystem services that are of fundamental importance not only to poor people but also to the survival of humans on this earth (Ostrom, 2010). Finding better ways of abstracting, using, and disposing of water resources in a global scale will determine our capacity to (a) address the problem of aquatic biodiversity, (b) provide ecological services (notably to alleviate poverty), (c) ensure safe sanitary conditions, ${ }^{5}$ (d) generate hydropower, (e) provide source of food and drink, and (f) ascertain that people continue to enjoy the aesthetic beauty and recreational activities that water areas offer (Ostrom, 2010; Stern, 2008). The global context of water scarcity, increasing global population, and rising demands from manufacturing, thermal power, and domestic use exacerbates the urgency of finding more responsible solutions for water management.

If all water users are change agents who affect and are affected by water quality and quantity variations (UN Water, 2012), past attitudes in many cases were of an expectation of governments to manage water as a "sector." Decision makers in other "true" sectors (food, energy, health, and others) paid little attention to how their actions affected water quality and quantity variations (and other users; Mariola, 2011). These attitudes have created a relative disconnection between policies and actions, and the role of managing both their consequences (UN Water, 2012). Implicit in the view of water management is that the role of the State in global economy has been considered an unavoidable intervention to substitute for feeble private initiative.

In this context, the need for voluntary action by firms towards the protection and preservation of water might have been largely underestimated in preference of coercion through policy intervention. But the "relationship" between private for-profit organisations and water resources is undergoing a major shift. Increasingly, industry leaders in different sectors (e.g., General Motors, Ford, Toyota, Intel, Nestlé, Unilever, and Coca-Cola) recognise freshwater as the Earth's most valuable and fastest depleting resource, and its availability a more critical problem than energy conservation (Caplan, Dutta, \& Lawson, 2013). Some of their production sites are located in regions currently enduring, or forecasted to endure, water stress or water scarcity, which represents a direct threat on their production levels, profit margins, and even "license to operate" (Barton, 2010). Firms are exposed to (long-term) operational and economic risks due to water scarcity or flooding, water quality, or variability of either (Chalmers, Godfrey, \& Lynch, 2012). The relation of interdependency that exists between sustainable business performance and the protection/preservation of water resources suggests that a debate on corporate water responsibility is necessary. Willmott (2012) recognises water as one of the "problems," in which business and management contexts are implicated, that have the widest social consequences or "legacy."

Decades of research into corporate social responsibility, sustainability, corporate citizenship, and business ethics ushered management thinkers and practitioners into deeper knowledge of the 
broader socio-ecological challenges of business activities such as those linked to the management of water. Some scholars point to an important gap in this literature: the failure to generate a realistic alignment between business enterprises and the socio-ecological (including hydrological) realities of our time (e.g., Browne \& Nuttall, 2013; Fooks, Gilmore, Collin, Holden, \& Lee, 2013; Lorenzo-Molo \& Udani, 2013; Sun \& Cui, 2014). Critics highlight the lack of knowledge that can be used to predict and control the nonhuman world, including the interplay of human agency and the autonomous dynamics of water (Rice, 2013). As a case in point, corporate social responsibility initiatives are too often undertaken in isolation to the wider socioeconomic context of the firm (Visser, 2014). They tend to concentrate on measures that further the immediate interests of the corporation, while taking a narrow view of the relevant external stakeholders and producing scattered social benefits (Fooks et al., 2013). ${ }^{6}$ What is more, the instrumental and deterministic rationale that has long prevailed (and still prevails) in industrial society in general, and environmental strategy management in particular, is based on elements such as efficiency gains and the mastery of technological innovation over nature that appear to be insufficient on their own to avert (and perhaps reverse) the negative impact of individual and collective (business) enterprises on society (Murphy, 2004; Starik \& Kanashiro, 2013).

If the failure of traditional corporate social responsibility to deliver realistic and useful solutions for both companies and society (Browne \& Nuttall, 2013) is partly responsible for the lack of progress in developing substantively more sustainable business and production/consumption systems for managing water, then it suggests a need to explore other approaches. Arguably, both the improvement of water quality and the availability of clean water in communities throughout the world, especially in emerging markets, require exploring the phenomenon of water management by business organisations in considerably more detail than is possible in traditional corporate social responsibility thinking.

Against this backdrop, this article provides an overview of the challenges faced by for-profit business organisations in developing, implementing, and sustaining effective water management strategies and operations. Bridging knowledge domains, I review major research works conducted by management, corporate sustainability, and (welfare) economics scholars and focusing on water management issues to present preliminary support for the conceptualisation of corporate water responsibility.

As a result, this study makes two important contributions to the literature on business sustainability. On one hand, it focuses on an important aspect of corporate social and environmental sustainability that has received scant attention in this literature and is not yet examined from a management oriented perspective - that is, the business approach to water management. Kurland and Zell (2010) conclude a review of water-related articles published in business journals: "Research that places water as central rather than take it for granted will help make business research relevant to an increasingly water-constrained planet" (p. 345). A critical assessment of research on the management of water by business organisations will thus provide a timely contribution to our knowledge of this phenomenon, let alone to the fact that society has a growing expectation that the private sector, often perceived as complicit in global water threats, should bear responsibility for their impact on water (Lambooy, 2011).

On the other hand, the discussion spans a range of theoretical orientations and analytic approaches, drawing essentially on work in ecological/environmental economics and management theory. In doing so, it helps identify explicitly the challenges faced by business organisations in managing water and explores potential solutions for more sustainable abstraction, use, and disposal of water by business - the first of this kind in "organisation and environment" studies. Current business sustainability theory is not well suited to this purpose because it neglects the question that motivates this article: What are the conditions under which corporations are likely to manage, or to be challenged in managing, water in responsible/sustainable ways? 
I begin with a brief review of the literature on water management to identify some important clues that will help focus discussion on the firm-level conditions under which corporations are more or less likely to contribute to the sustainable management of water.

\section{The Issue of Water Responsibility in Business}

One challenge of water management discussed by Espínola-Arredondo and Muñoz-García (2011) and Ostrom (2010) is equity in the distribution of water resources among a variety of stakeholders in the private and public sectors. The equity goal arguably requires institutional arrangements and management decisions that promote the efficient use (or preservation/conservation) of water resources as well as cost recovery. A situation of full cost recovery ${ }^{7}$ is arguably desirable to achieve resource conservation (Barberan \& Arbués, 2009) so as not to undermine the integrity of (and the benefits people obtain from) water ecosystems. ${ }^{8}$ The fact that private and public organisations have open and often unrestricted access to physically and temporally dynamic water systems (otherwise referred to as "common pool resources" or "commons") might explain some of the difficulties encountered by policy makers in evaluating the external cost of water services (and therefore defining the sustainable value of water; Rogers et al., 1998) on the basis of which water pricing may be optimised and cost recovery strategies that contribute to the equity goal by matching water demands both for quantity and quality with water supplies may be devised. There is no shortage of (welfare) economics studies reporting evidence of unresolved inequities and inefficiencies in the abstraction, use, and disposal of water. Examples might be found in studies of water resource allocation and optimisation (Asche, Roll, \& Tveteras, 2009), water pricing (Ansink \& Houba, 2012; Nataraj \& Hanemann, 2011), water (and virtual water $^{9}$ ) trades (Aldaya et al., 2010; Novo, Garrido, \& Varela-Ortega, 2009), property rights (Cox \& Ross, 2011; Kremer, Leino, Miguel, \& Zwane, 2011), transboundary water usage and pollution (Gren, 2008; Zhang, Yang, \& Shi, 2011), and willingness to pay or the involvement of behavioural influences on the management of water (Pfeiffer \& Lin, 2012; Spash et al., 2009).

The interrelated and often conflicting goals of equity, efficiency, and ecological integrity (Postel, 1992) were all expressed in the Rio Summit's Agenda 21 Chapter (1992) on Freshwater as critical components of integrated water resources management. The integrated water resources management framework was developed by the Global Water Partnership (2000) to foster the sustainable development, allocation, and monitoring of water resource use in the context of social, economic and environmental objectives (Cuickshank \& Grover, 2012). Although some evidence suggests that the framework can help firms identify the broad capabilities that are required to foster the optimisation of water usage and the reduction of wastewater quantities (see, e.g., Dvarioniene \& Stasiskiene, 2007), a number of objections have been raised to explain a relative lack of impact. Some commentators question the clarity of the framework, suggesting that it fails to provide a guide for practical action (Cook \& Spray, 2012; Merrey, 2008). Merrey refers to "integrated water resources management" as a religious text providing a set of unquestioned assumptions and assertions about how water should be managed. What is more, the tendency of the framework to disregard knowledge that does not meet positivist expectations leads to the neglect of the social causation processes involved in (and social constructionist explanations on) water management to which Cook and Spray (2012) and Wissenburg (2013), for example, draw our attention. Last but not least, because the lack of breadth of integrated water resources management enables many individuals/firms to suit the concept to their own interests (Cook \& Spray, 2012; Hill, 2013), one may question how overly technocentric corporations (Gladwin, Kennelly, \& Krause, 1995; Valente, 2010, 2012) may be incentivised to protect water as essential to sustaining life rather than merely an economic good yielding immediate reputational and financial benefits. What this implies is that studies of corporate water responsibility might benefit greatly from 
a broader consideration of motivational antecedents and the possible tensions between (ethical) corporate water responsibility motives and (instrumental) economic motives.

One rationale for corporate water responsibility beyond short-term economic gains is that business activities affect - and are affected by - the societal issues and economic costs linked to water use (Porter \& Kramer, 2011). The strategic implications of managing water for businesses have not yet emerged as a significant problem among business and management scholars, perhaps because the institutional, political, and economic problems related to water allocation mechanisms and water pricing that dominate the debate on water management (Olmstead, 2010) have historically been perceived as a subject for economic inquiry and decision (Wissenburg, 2013). Another reason might be that from a business perspective, water is generally treated as a free good not worthy of strategic consideration (Jones, 2010) or as a relatively inexpensive source of energy for production that may represent an economically viable substitute to the more costly nuclear, coal, gas, and fuel when energy demand is high (Aïd, Chemla, Porchet, \& Touzi, 2011). What has been disregarded, however, or left unanalysed in business, is that the capacity of this source of energy is limited not only by the volume of water available ${ }^{10}$ but also by the quality of the water available in specific regions (Aïd et al., 2011). This raises one important question: How do/will firms manage to cope with global water quality and quantity problems without undermining their economic viability, and perhaps by considering responses above and beyond what the law requires?

Because business activities are often "water intensive" and may provoke the discharge of various types of polluters in the water, they play a considerable part in creating water shortages and quality problems. Enhancing businesses' resource efficiency on the basis of water footprint ${ }^{11}$ analysis is one way of reducing water use intensity (DEFRA, 2011). Companies in the food and beverage sector have tended to rely on water-footprinting methodologies to increase water efficiency and mitigate business water-related risks (Chapagain and Tickner, 2012; The Coca-Cola Company and The Nature Conservancy, 2010; SABMiller \& WWF, 2009). But these companies have begun to realise that efficiency alone is not sufficient to warrant sustainable management of water in the face of the geo-spatial complexity of water risks (Money, 2014). There is also a necessity to ensure equitable access to clean water so that society can enjoy food security, basic sanitation, and ecological integrity. The ultimate goal of corporate water responsibility is that companies contribute to ecological integrity via the efficient and equitable abstraction, usage, and disposal of water resources.

The institutional and management challenges faced by, and solutions offered to, business leaders to develop, implement, and sustain the integration of corporate water responsibility in strategies and operations remain underexplored. In a report on water scarcity, climate change, and the risks involved for businesses commissioned by a network of investors in the Pacific region, Morrison, Morikawa, Murphy, and Schulte (2009) observe that few companies and investors think strategically about the significance of sustainable water use. A simple Internet search of corporate names and the term water enables one to find that industry leaders like Nestlé, CocaCola, Unilever, Levi Strauss, and Intel support vehemently water stewardship initiatives. Yet the problems faced by both Coca-Cola in its bottling operations in India ${ }^{12}$ and Nestlé in its governance posture ${ }^{13}$ demonstrate that the integration of corporate water responsibility principles across the firm (i.e., in the design of governance choices, strategies, and operations) is neither guaranteed nor straightforward. These examples point to both the tendency of corporations to operate as insular entities or free riders across the world and the limitations of such a passive view of the role of business in society for the sustainable management of water. Pahl-Wostl, Conca, Kramer, Maestu, and Schmidt (2013) suggest that businesses ought to play a more active role as systemic entities within a global water governance framework that encourages cooperative initiatives and stakeholder dialogues. This article aims to specify the conditions under which businesses might contribute to this agenda. 
Management and corporate sustainability studies focusing on water-related issues are scarce (Whiteman, Walker, \& Perego, 2013). Discussions of such issues are generally limited to illustrations of arguments on broader business sustainability challenges (see,e.g., Kang, 2013; Peloza, 2009; Whiteman et al., 2013). They also tend to be limited to a focus on a water company or an industry rather than the resource itself (Kurland \& Zell, 2010). Willmott (2012) confirms that water-related issues have been largely ignored in business and management literature and education as their contents say little or nothing about the way companies (ought to) manage water. Because a shift towards more sustainable ways of abstracting, using, and disposing of water critically depends on the capacity of business and management practitioners to propose and implement corporate water responsibility solutions, a critical assessment of the literature addressing the phenomenon of corporate water responsibility may have general usefulness for management theorists and practitioners seeking to inform, and contribute to, the protection and preservation of water.

In order to examine the challenges of corporate water responsibility and define the variables that compose its construct, I review a selection of studies conducted by scholars in the fields of business/management, business sustainability, and organisational and welfare economics. The (organisational and welfare) economics literature provides a rich platform from which to understand the challenges faced by various parties (including businesses) in managing water. Insights from scholars in this field are one particularly (if not the most) important source of information for policy decisions and practice in the domain of water management.

An integrative (or summative) literature review seems well suited to the objectives of this article to explore the challenges of water management by business organisations in an area where scholars, practitioners, and policy makers can expect new questions, problems and challenges in the years ahead. I apply Torraco's (2005) guidelines on the process of integrative literature review $^{14}$ to develop the construct of a corporate water responsibility framework in the field of organisation and environment, and propose a research agenda. The review focuses on published business/management and (welfare) economics (conceptual and empirical) articles devoted in some ways to the management of water by business organisations. Because the disciplinary focus of academic journals is generally clearly defined as a set of research themes and issues of interest that are traceable on the Internet, the process of interdisciplinary integration pursued in this article is transparent, verifiable, and less abstract than if books, reports, newspapers, and popular magazines were added to the list of literature sources. The Scopus search engine was used to browse two sets of keywords: (a) water (in article title, abstract, keywords) AND business OR management (in source title) and (b) water (in article title, abstract, keywords) AND economy OR economics OR economic (in source title). I relied on ISI Web of Knowledge (Journal Citation Reports) to focus the selection on journals with an impact factor superior or equal to 0.5. ${ }^{15}$ The journal Organization \& Environment was also included because of its likelihood to publish articles focused on business and the natural environment. I systematically excluded articles that appeared in the search because the author's name is Water or the term water is used in a metaphorical way such as in "troubled waters." I established a starting point for the research at 2007. This seems justified, as the issue of water management was brought into sharper focus by the UN's Human Development Report emphasising the link between power, poverty, and the global water crisis and encouraging the engagement of academics, industry leaders, and governments in cooperation for research into water management (UN Development Programme, 2006; UN Water \& Food and Agriculture Organization of the United Nations, 2007; Water Resources Group, 2013). From then on, "business" research on this topic became a consistent stream that has not yet permeated substantially the mainstream of business and management research. This explains the disproportionate ratio of 63 business/management articles to 541 (welfare) economics articles in the final data set (see Table 1 for a list of the literature sources reviewed). 
Table I. Academic Sources Selected for Review.

Discipline Academic journal (No. of articles)

Business and management

Academy of Management Learning \& Education (I), Academy of Management Perspectives (I), Academy of Management Review (I), Business \& Society (I), Public Management Review (I), Business History (3), Business History Review (3), Business Horizons (I), Business Strategy and the Environment (2), California Management Review (I), Corporate Social Responsibility and Environmental Management (3), International Journal of Project Management (6), International Journal of Contemporary Hospitality Management (2), International Journal of Physical Distribution \& Logistics Management (2), International Journal of Strategic Property Management (I), International Journal of Systems Assurance Engineering and Management (I), International Journal of Technology Management (I), International Public Management Journal (I), International Studies of Management \& Organization (I), Journal of Business Ethics (2), Journal of Business Logistics (I), Journal of Business Research (2), Journal of Knowledge Management (I), Journal of Product Innovation management (I), Journal of Purchasing and Supply Management (I), Management Accounting Research (I), Management Decision (I), Management Science (1), Public Management Review (3), Technology Analysis \& Strategic Management (3), Total Quality Management \& Business Excellence (3), Tourism Management (8), Strategic Management Journal (I)

(Welfare) economics

American Economic Review (4), American Journal of Agricultural Economics (25), Amfiteatru Economic (I), Annual Review of Resource Economics (4), Applied Economic Perspectives and Policy (I), Australian Journal of Agricultural and Resource Economics (3I), B.E. Journal of Economic Analysis \& Policy (2), Canadian Journal of Agricultural Economics (16), CESifo Economic Studies ( I), China \& World Economy (I), China Economic Review (8), Contemporary Economic Policy (I0), Ecological Economics ( 175), Economic Development and Cultural Change (I), Economic History Review (I), Economic Inquiry (I), Economic Journal (2), Economic Modelling (4), Economic Record (3), Economic Systems Research (I0), Economics \& Human Biology (3), Empirical Economics (I), Energy Economics ( I0), Environmental \& Resource Economics (4I), European Journal of Political Economy (I), European Review of Agricultural Economics (3), Explorations in Economic History (I), Games and Economic Behavior (1), Health Economics (2), International Environmental Agreements: Politics, Law and Economics (16), International Journal of Finance \& Economics (3), International Review of Environmental and Resource Economics (3), Journal of Agricultural and Resource Economics (10), Journal of Agricultural Economics (8), Journal of Business \& Economic Statistics (I), Journal of Development Economics (7), Journal of Economic Behavior \& Organization (I), Journal of Economic Dynamics \& Control (I), Journal of Economic Psychology (I), Journal of Economic Surveys (2), Journal of Environmental Economics and Management (I6), Journal of Forest Economics (I), Journal of Health Economics (4), Journal of Housing Economics (1), Journal of Law \& Economics (I), Journal of Law, Economics, \& Organization (2), Journal of Population Economics (I), Journal of Public Economics (I), Journal of Real Estate Finance and Economics (I), Journal of Regulatory Economics (5), Journal of Sports Economics (I), Journal of the Asia Pacific Economy (2), Journal of the Austrian Society of Agricultural Economics (I), Journal of Urban Economics (I), Labour Economics (I), Land Economics (20), Marine Resource Economics (6), Oxford Economic Papers (I), Oxford Review of Economy Policy (I), Pacific Economic Review (I), Quarterly Journal of Economics (3), RAND Journal of Economics (2), Regional Science \& Urban Economics (2), Resource and Energy Economics (8), Review of Agricultural Economics (7), Review of Development Economics (1), Review of Environmental Economics and Policy (10), Review of International Economics (I), SocioEconomic Planning Sciences (4), South Asia Economic Journal (I), Southern Economic Journal (I), Spatial Economic Analysis (I), Technological and Economic Development of Economy (6), Tourism Economics (3), Transformations in Business and Economics (1), World Bank Economic Review (I), World Economy (I)

I performed a water-focused review of the selected literature, weaving the streams of research together to focus on core water-related issues rather than merely reporting previous literature. ${ }^{16}$ In doing so, I explore several "tensions" that appear to be associated with the phenomenon of corporate water responsibility and to hold an influence on the corporation: voluntary 
action versus coercion, free riding versus cooperation, and economic versus corporate water responsibility motives. This article provides a synthesis of the key points that characterise each type of tension and guide towards the development of a framework for corporate water responsibility that yields plausible solutions and directions for future research.

\section{Tensions and Plausible Solutions}

\section{Voluntary Action Versus Coercion}

The first type of "tension" in the practice of corporate water responsibility is linked to the relationship between business and water regulations. While the complexity of managing water suggests that a certain level of freedom for action is required in order to enable contingent and flexible water responsiveness (Simpson, Power, \& Klassen, 2012), regulating may be a necessary catalyst when a firm's level of corporate water responsibility fails to generate improvement in practice and the market failures created by water scarcity and quality deterioration need to be addressed. However, regulations alone are not enough. Some commentators explain that businesses that seek mere compliance may not produce the level of information that is necessary for finding more sustainable ways of managing water, especially when a lack of incentives for acting (i.e., measure, report) generates defiance and/or patterns of corruption emerge (see, e.g., Bui \& Kapon, 2012; Evans, Gilpatric, \& Liu, 2009). One study of ISO 14001 environmental management system certification among 433 automotive plants in Mexico conducted by Montiel, Husted, and Christmann (2012) confirms that corrupt business environment creates information asymmetry between insiders and external stakeholders, making corporate water responsibility unlikely to benefit from existing regulation and certification systems.

Organisational capabilities to drive change towards more sustainable ways of managing water might be reinforced in a context where internal and external auditing processes are self-imposed and regulation is no longer the primary motive for managing water responsibly. Montiel et al. (2012) propose the use of credible private management standard certification by selecting reputable auditing firms from foreign countries with low general corruption. Because these auditors may be perceived as less susceptible to domestic corruption and more capable of detecting inaccurate information, their involvement can act as a remedy to the potential unreliability of compliance approaches in a specific region/country (Montiel et al., 2012).

Building upon firms' existing capabilities, notably to develop local knowledge through auditing, may be more effective in improving water resources performance than developing, and striving to comply with, industry standards and local water regulations (Simpson et al., 2012). Cason and Gangadharan (2012) support the idea that a combination of choice and coercion may result in effective water management. They emphasise the need to combine voluntary engagement and self-restriction grounded in a formal system. In some cases, pressure from an external agent or auditor (e.g., nongovernmental organizations, regulators, consumers) can encourage the formation and enforcement of social norms within and across groups (Cason \& Gangadharan, 2012). For example, the enactment of the U.S. Clean Water Act, a federal U.S. regulation that sets limits on pollutants discharged into surface waters by industrial facilities, was followed by voluntary water reporting and management initiatives from businesses (Chakraborti \& McConnell, 2012). Information about a company's management practices and performance disclosed pursuant to government regulations can stimulate management to pursue changes in both (Chatterji \& Toffel, 2010). In a normative context in which social norms provide the motives and the meaning leading corporations to explicitly account for the water-related market failures that are held to play a critical role in business performance, firms may be encouraged to develop/establish in-house methods and acquire external expertise/knowledge aligned with the hydrological realities of our time, both integrated into the firm through departments, functions, vision, and strategy. However, 
in a normative context in which business decisions are primarily informed by market-based financial calculations (or cost-benefit analysis), the negative relationship between clean water regulations and expected financial performance found by Rassier and Earnhart (2010) may disincentive compliance and voluntary action for corporate water responsibility. It may also explain the emergence of defiance postures.

\section{Free Riding Versus Cooperation}

A second approach to framing the challenges involved in corporate water responsibility has focused on the tensions between free riding and cooperation. Drawing from Desrochers (2010), the notion of free riding refers to a pattern of free and unrestricted commercial access to water without clearly defined and enforced (whether individually or communally) property rights. Messerlin (2011) explains that water, as a prominent economic problem, has a heavy dose of free riding. Water and wastewater utilities are governed by "natural monopoly" features (Marques \& De Witte, 2011) so that competition is rare and, although collective actions are required (Messerlin, 2011), incentives to participate in water protection and preservation activities are lacking. These features are viewed by the business scholars Reed and Reed (2009) and Utting and Zammit (2009) to pose a threat on sustainable water management. A somewhat more optimistic observation by Desrochers (2010) is that privatization of commons turns the pursuit of selfinterest from an apparent vice into a social virtue as private owners have strong incentives to maintain and increase the value of their assets for future sale, often at the expense of water affordability by the poorest fragments of population (Ostrom, 2010). A contrasting argument is that free riding firms may be more concerned with water cost reduction than the value of water for future sales (Aïd et al., 2011; Jones, 2010). The pattern of free riding, combined with a form of resistance from firms to participate in both collective actions and knowledge enhancement campaigns for sustainable water management, arguably affects the development of effective solutions for corporate water responsibility. Unless a comprehensive cooperative agenda is in place and innovative institutional arrangements can be developed, the tendency of free riding to promote the avoidance of accountability by businesses and disincentive their participation in water protection and preservation activities may gain momentum and current water inefficiencies and degradations may continue to increase beyond the radar of the firm.

There is consistent scholarly interventions in favour of coordination, cooperation across sectors (e.g., public private partnerships), value chains, and business functions as well as enhanced corporate awareness/visibility regarding complex water quantity and quality issues (e.g., González-Benito \& González-Benito, 2010; Rueda-Manzanares, Aragón-Correa, \& Sharma, 2008; Utting \& Zammit, 2009). Two major reasons are identified to justify this posture. On one hand, establishing property rights and predicting physical movements of water is difficult (Van den Brink, Van der Laan, \& Moes, 2012), suggesting that the type of coalition for water management is context related and contingent on regionally distinct spatial and temporal variations of blue (groundwater and stream flow) and green (soil moisture) water, let alone the salience of socioeconomic and policy conditions (Novo et al., 2009; Rueda-Manzanares et al., 2008). On the other hand, water management is often observed to be partially influenced by behavioural aspects and (power) dynamics between institutional actors (e.g., Lieberherr, Klinke, \& Finger, 2012; Schaefer, 2007). Exactly how these dynamics might result in cooperative and coordination efforts that provide for strong corporate water responsibility remains to be explored in studies involving a large sample of company cases. In discussing an example of partnership between Unilever Indonesia and the Indonesian ministry of the environment to create a "clean river program" that would substantially improve water quality in Indonesia, Bouquet and Birkinshaw (2008) point to the challenge posed to water management by the power relations between actors in the multinational company network, especially in a context where information systems and processes do not 
have the necessary alignment in order to automatically track information about water usage (Wolf, 2011).

Rueda-Manzanares et al. (2008) portray service firms as singularly prone to adopt of the free rider's posture in their approach to water. Their study indicates that progress towards more sustainable management of water by service firms would require not only self-imposed monitoring (e.g., water footprint analysis) and restrictions but also a shift in internal thinking from a narrow view (i.e., "Firms are insular actors - they stand apart from society, therefore they are not concerned about the societal consequences of water [mis]use") to a holistic view (i.e., "Firms are integral part of a wider system and able to influence value chains, engage with communities, and form coalitions with stakeholders - therefore they may play a leading role in fostering progress towards water sustainability").

A number of scholars converge on the idea that participatory processes involving policy makers, business organisations, citizen's organisations, and "water experts" allow unveiling of framings, perspectives, values, and interests; compensate the lack of information about contributions to water pollutions in some contexts; as well as understand the social and institutional context in which the waters are governed (e.g., Collins \& Maille, 2011; Lennox, Proctor, \& Russell, 2011; Paneque Salgado, Corral Quintana, Guimarães Pereira, del Moral Ituarte, \& Pedregal Mateos, 2009). The need for adaptive solutions to address the technical (spatial and temporal variations of water), informational (information asymmetry), and relational (power dynamics) issues of (co-)managing water resources suggests that the free riding pattern driving firms to operate as "insular entities" (standing apart from society and pursuing their own instrumental interests) is no longer possible. As a case in point, Messerlin (2011) explains that public-private partnerships in water management are a necessary condition to elicit a negotiated and coordinated response to water quantity and quality issues, yet they require that an urgent trust-building exercise among the climate, trade, and water communities takes place. This acts to reemphasise the importance of context-related and participative coordination (and cooperative efforts involving businesses with industry peers, suppliers, policy makers, nongovernmental organizations, and "water experts") where firms are committed to improving our knowledge of (and facilitating our access to information about) water (co-)management that promotes equitable access to water. In doing so, companies ought to adopt a leadership position in research and development, setting industry standards on water usage and disposal, asking suppliers to also adopt the highest standards of water sustainability, and partnering with governments to develop and share technologies (Cason \& Gangadharan, 2012).

\section{Economic Versus Corporate Water Responsibility Motives}

Finally, a third stream of research in relation to corporate water responsibility has focused on the process of strategy formation and its motivational antecedents. Some studies point to a link between strategy formation, individual behaviours/motivations and corporate water responsiveness. A particular emphasis is given to the positive influence of independent and inspirational leaders (e.g., Schaefer, 2007; Wu \& Pagell, 2011). The process of strategy formation is imbued with tensions between market-based calculations/economic motives and "nonmarket" corporate water responsibility motives. One contention is that greening the economy and developing solutions to protect and preserve water (presumably in a system where people consume less, spend less, and work less) will reduce the pace of economic growth. Another contention, noted by Gladwin et al. (1995), is that economic growth will suffer from environmental trends such as water scarcity and pollution; therefore, corporate water responsibility solutions, and integration of "nonmarket" costs and benefits, are necessary. The economics scholars Fleurbaey and Tadenuma (2007), and Lohmann (2009) converge on this argument as they point to both the limitations of market-based solutions/calculations and the failure to include nonmarket values and 
calculate all social costs. Corporate water responsibility should be informed not only by costbenefit numbers but also by intangible factors and other "unmarketed factors" (Lohmann, 2009), including the social consequences of water shortages and pollution that businesses play a part in creating and increasing.

In a study of U.K. water and sewerage industry, Schaefer (2007) argues that approaching corporate water responsibility as a source of competitive advantage, so that companies need to win contracts in competitive markets, may facilitate and rationalise a firm's engagement. She also finds that the pursuit of increased legitimacy in management innovation and the exclusive adoption of market-based solutions for strategy formation may be detrimental to environmental performance. Conforming to institutional pressures can result in improved economic performance but not necessarily in realising the original public good (e.g., reduction of water pollution) purpose of the innovation (Schaefer, 2007).

Visionary individuals and enlightened leaders, according to de Villiers, Naiker, and van Staden (2011) and Scodanibbio (2011), are important features of good corporate water responsibility performers. Related to the need for water management leadership and vision is the question of how individual leaders may be empowered to make a positive contribution to corporate water responsibility. de Villiers et al. (2011) use the example of British Petroleum's chief executive officer replacement in 2010 to support the idea that higher director independence and lower concentration of directors appointed after the chief executive officer can assist the board's ability to monitor and promote the environmental practices of the firm through (a) contesting the strategic choices and preferences of the firm with respect to environmental choices and orientation and (b) questioning the chief executive officer about better safety measures and pollution controls.

In a study of decision making in sustainable supply chain, Wu and Pagell (2011) argue that enhancing the capacity of the firm to identify an initial environmental opportunity or need (notably in water management) may lead to future opportunities and changes that are possible because of both accumulated learning and changes taking place in the organisation's operations and supply chain infrastructure. They discuss the experience of Forest and Wood Products' decision to stop the abstraction of water from local rivers and the positive effects of this decision on resource efficiency and water shortages in the region. Two critical success factors are highlighted by $\mathrm{Wu}$ and Pagell (2011): (a) the initial decision to stop taking water that forced managers to reengineer the production process and (b) the motivation of workers who saw immediate benefits from their efforts in terms of facility efficiency and in their community's water supply. One plausible deduction from this study is that willingness to reduce environmental impact and water usage translates into decisions and actions, generates a momentum of specialisation inside the firm, improves "business water performance," and ultimately increases "community water supply." The visibility of improved efficiency and water supply is identified as a key motivator for engaging individuals in a sustainable journey.

A stream of scholarly research covered in this study corroborates the idea that economic motives and operational efficiency are no longer good enough on their own to drive the changes necessary for sustainable water management, although they may generate instances of "win-win" gains in the short term. The importance of behavioural responses, the need to integrate nonmarket values and calculate all social costs, suggests that commercial businesses may identify new opportunities in water management if they combine the quest for economic returns and improved operational efficiency with a long-term vision shared among all relevant stakeholders and strong moral leadership propounding the "achievement of common good goals" (Lieberherr et al., 2012, p. 927). The examples discussed above (British Petroleum and Forest and Wood Products) demonstrate that combining these elements in business may enable organisational and operational changes for improved water management. The term integrated is often used to reflect attempts at managing competing institutional logics and achieving reconciliation between sustainable water use, human needs, broad community values, and economics (e.g., Hess \& Beharry-Borg, 2012; Pahl-Wostl et al., 2008; Spash et al., 2009; Volk et al., 2008). 
The integration dilemma is evident as a contemporary management issue in the broader literature on business sustainability (Gond \& Crane, 2010), which appears to be inciting scholarly interests in a variety of research axis including complexity science (Valente, 2012), hybrid organisation (Pache \& Santos, 2012), institutional polycentrism (Batjargal et al., 2012), and syncretism (Martinez, 2012, 2013). The application of these "pro-integration" perspectives on corporate water responsibility is commendable, especially when we consider that multiple motives and values are relevant to management decisions on the sustainable use of water (Schaefer, 2007; Spash et al., 2009) and internal shifts in thinking are necessary to achieve this goal (Scodanibbio, 2011). Bridging the gap between instrumental (economic) and ethical (corporate water responsibility) values/motives in business, and accounting for various and possibly diverging stakeholders' interests, might play a critical part in fostering progress towards reconciling water protection and preservation goals with economic performance. The approaches recently adopted by business sustainability scholars to tackle the integration dilemma cited above might be fruitful in this sense, let alone the concept of value attunement (Swanson, 1999) as a potentially relevant perspective from which to understand how firms may integrate multiple values within corporate water responsibility.

\section{Synthesis: A Three-Dimensional Conceptual Framework}

In summary, three types of tensions are discussed in this study, which allows us to distil the conditions under which corporate water responsibility can contribute (and/or is challenged in contributing) to the advent of sustainable management of water by business organisations - that is, a combination of voluntary (auditing) action, leadership in research and development, stakeholder engagement, and an integrated approach that embraces concern for human needs and ecological equilibrium in the pursuit of business economic sustainability. The discussion also indicates that a combination of "negative" corporate stances such as defiance (or corruption), free riding, and pure economic motives (i.e., water management to achieve cost reduction and operational efficiency) is likely to generate inefficient and/or inequitable exploitation of water.

Figure 1 puts these aspects together into a corporate water responsibility framework. The framework visualises how the concept proposes to break new grounds by distinguishing between the features that characterise different stages of business commitment to water management. Stage 1 represents conventional business approaches to water management where engagement is limited to the exploitation of business economic gains. Where water is assigned weak (or no) economic value, both efficiency and equity goals may be discarded, impeding the search for outcomes beneficial to business and "sustainable use" of water. Stage 2 is imagined as a form of progress from traditional, inward-looking business models towards a better alignment of business goals with water demand. The focus on competitive advantage means that efficiency and productivity gains through responsible water management are likely to be explored and exploited. Where the availability of freshwater for other users is not conceived of as strategically salient, the equity goal may be discarded. Stage 3, where businesses manage water efficiently and equitably (thereby striving to operate within water quantity and quality limits), remains largely underexplored in the organisation and environment literature.

In the framework, the $X$-axis reflects the discussion on the tensions in corporate water responsibility between voluntary action and coercion. Here, the business manager is able to evaluate his or her company's response(s) to public policy on a continuum from defiance to compliance to voluntary engagement. In this article, I argue that voluntary initiatives leading to, for example, internal and external auditing foster changes in strategies and operations that are more likely to generate higher stages of corporate water responsibility aligned with social norms and hydrological realities than defiance (Stage 1) or mere compliance (Stage 2). I thus converge on Rivera's (2010) framework for understanding the relationship between protective public policies and 


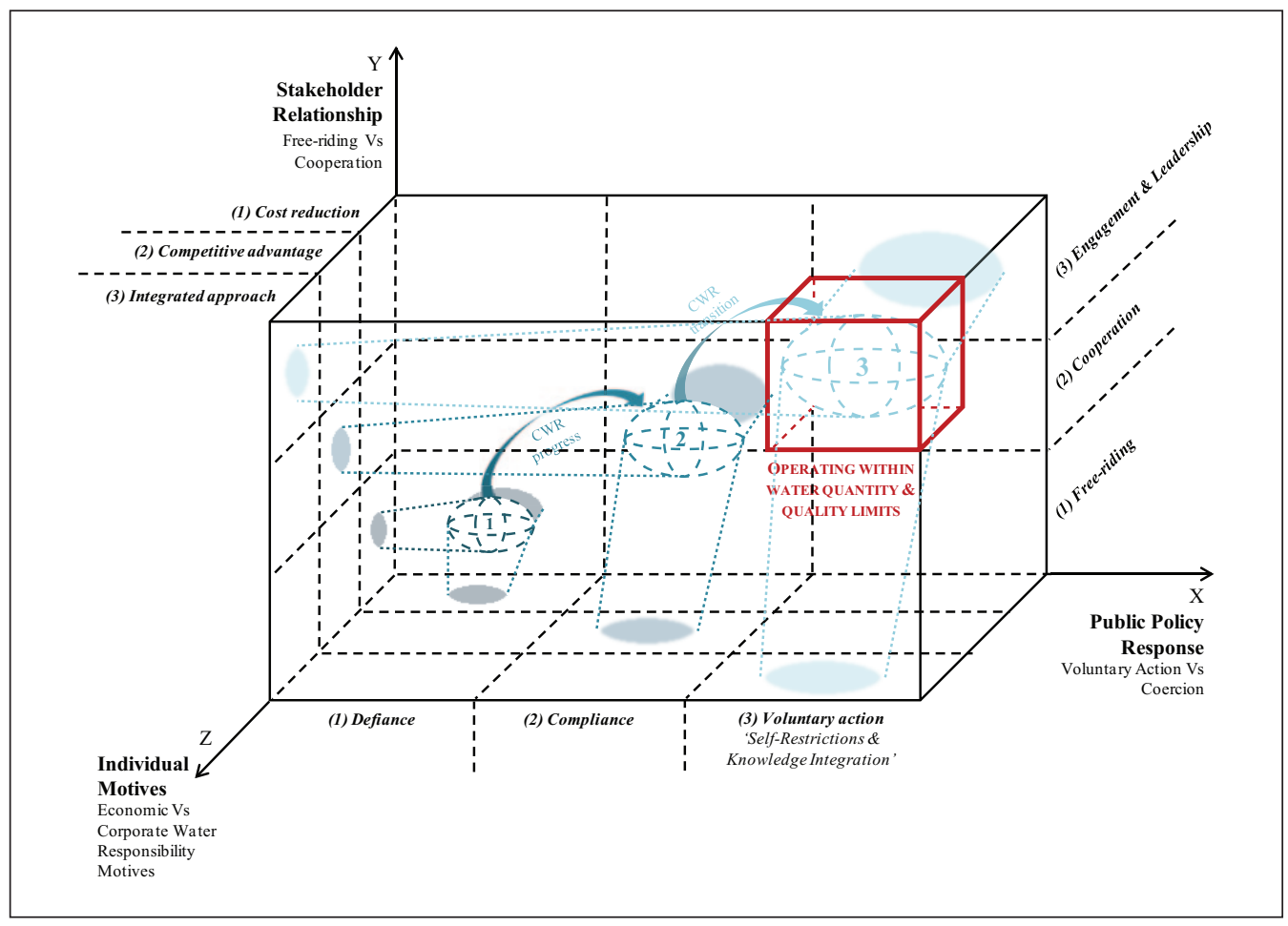

Figure I. The corporate water responsibility framework: A firm-level perspective on water resources management.

business compliance. At Stage 3, companies participate in voluntary agreements. They follow (and/or contribute to the development of) beyond compliance standards globally.

The $Y$-axis reflects the discussion on the tensions in corporate water responsibility between free riding and cooperation. Here, the business manager is able to evaluate his or her company's relationship(s) with stakeholders on a continuum from free riding to cooperation to engagement and leadership. In this article, I posit that corporate water responsibility requires a shift in the management of stakeholder relationships from firms as insular entities inwardly focused (free riding) to firms as systemic entities interested in building pro-sustainability connections with society not only for symbolic reasons but also, more important, for advancing corporate water responsibility in a proactive, stakeholder-engaging way (Stage 3).

Finally, the $Z$-axis reflects the discussion on the tensions in corporate water responsibility between economic and corporate water responsibility motives. Here, the business manager is able to estimate his or her corporation's motives on a continuum from cost reduction to competitive advantage to integrated approach. In this article, I argue that a firm's focus on "efficiency gains" postures might relegate corporate water responsibility into a particular set of strategic challenges and opportunities for companies that may prove a source of cost elimination and ultimately competitive advantage and differentiation (Hart, 1995; Russo \& Fouts, 1997), rather than recognise it as a more fundamental challenge to the long-term survival of the firm or as essential to sustaining life. At Stage 3, corporate water responsibility goes beyond the firm's profit goals to include a commitment to sustain the broader human and ecological needs of communities. The notion of "integrated approach" considers the normative/constructionist dimension of reconciling (competing) faiths within corporate water responsibility. 


\section{Uses of the Framework}

The framework is intended to be useful for both academics/researchers and industry/ practitioners.

For academics, the framework is primarily an aid to perceiving the unique features that characterise corporate water responsibility. What heretofore has been essentially regarded as an issue to be tackled by governmental institutions, and therefore not perceived as an important component of the value that is created for the institutional and private owners of profit-driven companies (Money, 2014), is explicitly treated here as a corporate responsibility. One aspect that has been particularly overlooked is the contribution of corporations to the water equity goal, requiring a combination of business resources and capabilities that have been given scant consideration in business and management research. The three dimensions of the model thus force scholars to think through the essential questions that must be faced in analysing corporate water responsibility and that traditional approaches to corporate social responsibility have only partly answered. The major use to the academics, therefore, is in helping systematise the important issues that must be taught and understood in an effort to clarify the corporate water responsibility concept. The framework is not the ultimate conceptualisation; it is rather a modest but necessary step towards understanding the major facets of corporate water responsibility

By extension, the framework can provide directions for researchers who seek to clarify the role of business actors in a global water governance framework. There seems to be a lack of legitimate and representative global leadership in water governance, mainly because the discourse of water and climate change emerged only about a decade ago (Pahl-Wostl et al., 2013). Businesses are often seen as powerful actors who can mobilise important resources to make their voice heard in governance settings. These resources might be used for effective implementation of global water management solutions if the narrative that "water is essential to business sustainability" becomes widely adopted by corporate leaders. It is hoped that this article will embark other researchers on a quest for making sense of this narrative so that it becomes part of the discourse and of people's meaning-generating processes, and ultimately increases the level of commitment of business actors as collaborators in global water governance systems.

Opportunities for researchers to test the conceptual propositions further could be explored in specific industry sectors and/or regions where water quantity and quality problems pose a serious threat on economic development and/or ecological integrity. In the United Kingdom, for example, the North Sea has long been a dumping ground for toxic materials. Therefore many rivers are badly polluted and the extensive use of pesticides and chemicals has led to a decline of biodiversity (Jones, 2010). From the evidence provided in this study, it is apparent that coordination and cooperation among private and public actors intended to ensure against such irresponsible practices may be impeded by various forms of relational problems related to, for example, power dynamics, positional interests, and the role of trust. Future research work on the topic might anticipate the fact that corporate water responsibility may develop as settlements among contending groups that seek to influence corporate policy.

For industry/practitioners, the conceptual framework can contribute to a shift of conception by arguing that water responsibility is not separate and distinct from economic performance but rather is a critical part of the total social responsibilities of business. The analysis integrates economic concerns into a corporate water responsibility framework. In addition, it places cognitive, motivational, and ethical aspects (cf. Z-axis, Figure 1) into a rational economic and legal framework.

Although the framework does not provide the answer to how far the organisation should go, it does provide a conceptualisation that could lead to a better managed corporate water management program: one that promotes business cooperative efforts and facilitates progress towards the exploration and exploitation of innovative ideas and technologies. Moreover, it can be used 
as a planning tool and as a diagnostic problem-solving tool. The framework can assist the manager by identifying categories within which the organisation can be situated. The average business firm is likely to face growing pressures to implement better water management systems and processes and might refer to the conceptual framework proposed in this article to analyse its stance on this issue and perhaps help determine its motivations, actions, and response strategies. Managers would therefore have a systematic framework for thinking through the managerial response patterns contemplated. The framework could serve as a guide in formulating criteria to assist the organisation in developing its posture on various socioeconomic issues related to water. The net result could be more systematic attention being given to the realm of corporate water responsibility. This could mean involving industry leaders in making purposeful changes that consider the uncertainties of global water dynamics and the impact of climate change (e.g., irregular rainfalls, floods, drought, Antarctic ice shelf melt, loss of biodiversity) as strategic stakes, as big as unpredictable.

The framework can also serve to tease out the internal and external barriers that are likely to impede corporations from an optimal level of commitment to corporate water responsibility. One internal barrier is the deeply rooted belief of individual agents of management that water is not salient to business. Therefore investment in water management is unnecessary. If a change of mind-set is desired to generate high stages of corporate water responsibility, it might be triggered by approaching corporate water responsibility as a realistic option for firms to have an economic competitive advantage over those that do not seek to adopt such a model. This approach provides not only an explanation for ethical firm behaviours but also a basis for instrumental appropriation of corporate water responsibility (economic growth). Stakeholder activism and political decision making are amongst the "external" forces that have the power to alter the perceptions and assumptions of corporate managers and might continue to conspire in ways that can change institutions and, therefore, the propensity for corporations to act in responsible ways towards the management of water. One potential barrier related to the influence of stakeholders might be the failure of governments to offer certain kind of incentives for corporate water responsibility-for example, in terms of tax allowances to water-efficient facilities, often more costly, and hence less economically viable, than conventional "water intensive" facilities. Another important barrier mentioned in this article stems from the complexity of evaluating the hydrological dynamics that a firm's activities may affect, or by which a firm's activities may be affected.

It is hoped that the implementation of internal and external auditing processes within corporate water responsibility can help overcome internal and external barriers by supporting (and promoting transparency in) the measurement and monitoring of water usage. These processes might facilitate independent substantive evaluation of companies' water management performance that provides directions for both corporate strategizing and public policy making. However, the problems of property rights, measurability, and data representation in water management mean that auditing processes are unlikely to be "error-free" (Evans et al., 2009). Scholarly and managerial attention might be oriented towards the development of reliable tools for improving transparency in evaluations of water quantity and quality in business.

One industrial domain in which the corporate water responsibility framework may establish its practical usefulness is agriculture. Current trends of increasing food and bio-fuel needs and changing water demands induced through climate change are expected to increase pressure on existing water allocation mechanisms, thus raising uncertainty about the sustainability of irrigated agriculture (Schaible, Kim, \& Aillery, 2010). Knapp and Schwabe (2008) explain that "water-neglecting" agricultural activities are likely to carry various types of nutrients, chemicals, or bacteria from fields into waterways, not to mention the difficulty of accounting for and defining water entitlements consistent with hydrological realities and water supply variability and salinity (Connor, Schwabe, King, \& Knapp, 2012; Ringer, Cai, \& You, 2008). The corporate water responsibility framework entails that internal and external auditing processes involving 
agricultural businesses with, for example, energy experts and environmental scientists (Smith, Eiswerth, \& Veeman, 2010) should facilitate the monitoring and verification of the quantity and quality of the water used (mostly for irrigation), as well as the linkages between water quantity and quality. Agricultural firms might become proactive agents of change in water management rather than respond/adapt to the decisions/policies imposed by governments (Level 3, $X$-axis).

What is more, the fact that agricultural businesses often operate in relative isolation is arguably unsuited to the objective of averting overextraction and pollution of water by agricultural firms. It also suggests that institutional reforms in governance of water allocation and water quality are necessary (Connor et al., 2012). Referring to the corporate water responsibility framework, such reforms should be partly prompted by the engagement and leadership of agricultural companies in multipartners water management projects (Level 3, $X$-axis).

Finally, increasing scholarly interest in motives, behaviours, and cultural characteristics of irrigators (e.g., Loch, Bjornlund, Wheeler, \& Connor, 2012; Pahl-Wostl et al., 2008) demonstrates that social constructionist explanations are not to be neglected in order to understand how progress towards sustainable management of water by agricultural businesses might be achieved. The operational/economic gains that agricultural firms may achieve via corporate water responsibility progress from Stage 1 to Stage 2 (cf. Figure 1) are not sufficient on their own to support the complexity of water quantity and quality problems. If the water comes for free and the maintenance work that is necessary to sustain irrigation channels is arduous, why would adjoining tenants voluntarily contribute and fight against the draining of the channels and others not (Habisch \& Adaui, 2013)? The integrated approach at the individual level (Level 3, $Z$-axis, cf. Figure 1), and multiple motives/values held by individual agents of management, considers the salience of looking beyond business rationality to respond to broader community concerns. As such, it might explain how corporate voluntary commitment and mutual cooperation in the management of water can be achieved. Hence Stage 3 (cf. Figure 1) provides for a more holistic, and potentially more realistic, appraisal of strong corporate water responsibility in agriculture.

\section{Conclusion}

This article takes a step towards clarifying the conditions under which corporations are likely to manage, or to be challenged in managing, water in responsible/sustainable ways. By reviewing major research works conducted by business/management and (welfare) economics scholars to analyse corporate water responsibility, this article weds two literatures that heretofore have remained largely isolated from each other. The key aspects of the conceptual framework of corporate water responsibility that the study unveils (cf. Figure 1) address major questions of concern to these academic scholars around the strategic, operational, governance, and individual/ cognitive aspects that influence a firm's capacity to foster progress towards more sustainable use of water. They also unveil interesting directions for business practitioners to systematise thinking about water-related issues, and to improve planning and diagnosis in the realm of water management.

As we enter the last lap to Horizon 2020 (European Union, 2013) and look ahead to avert the grim future painted by the Environmental Outlook to 2050 (OECD, 2012), it is expected that attention will be given increasingly to measurement initiatives as well as theoretical development of water management in general and corporate water responsibility in particular. As theory is developed and research is conducted in the area of corporate water responsibility, scholars may revise and adapt the definition of the concept or new definitions may come into the literature. However, at the present time, it is hard to imagine that these new concepts can develop apart and distinct from the groundwork (partly reviewed in this article) that has been established by business sustainability and, more extensively, (welfare) economics scholars. 
More than likely, we will see new realms in which to think about corporate water responsibilities in new and emerging technologies, fields, institutional arrangements, and economic models (e.g., Water Resources Group, 2013). In this context, it appears that the corporate water responsibility framework has a bright future because at its core, it addresses and captures one of the most important concerns of the public regarding business and society relationships. Arguably the research in this article presents fertile grounds for further theoretical and empirical analysis of corporate water responsibility. More interdisciplinary research efforts on the topic are particularly commendable, especially when we consider that environmentalists, city planners, geographers, lawyers, engineers, and sociologists have interesting and potentially determinant insights to provide on the firm-level and institutional challenges faced by business organizations in developing, implementing and sustaining sustainable water management strategies and operations. To whatever extent the framework presented here helps accomplish these objectives, it remains but a modest step towards a deeper understanding of corporate water responsibility.

\section{Declaration of Conflicting Interests}

The author declared no potential conflicts of interest with respect to the research, authorship, and/or publication of this article.

\section{Funding}

The authors disclosed receipt of the following financial support for the research, authorship, and/or publication of this article: This work was supported by the Centre for Business Relationships, Accountability, Sustainability and Society (BRASS) at Cardiff University.

\section{Notes}

1. Consider, for example, the UN Millennium Ecosystem Assessment (2005) and the Transparency International Corruption Perceptions Index. A recent report from the UN entails that "the development of water scenarios appears ever more necessary in the face of the risks and uncertainties involved in continuing with the 'business-as-usual' modes of water management" (UN Water, 2012, p. 12).

2. Meanwhile, the phenomenon of deforestation tends to disturb climate conditions by generating irregular rainfalls and a decrease in water supply (Ollivier, 2012).

3. Recognising that water is critical for sustainable development, the UN designated 2013 the Year of Water Cooperation, and will focus on lessons that can be learned from successful water cooperation initiatives.

4. In a study of the external water footprint of Dutch consumers, van Oel, Mekonnen and Hoekstra (2009) identify the following eight countries as most seriously affected: China, India, Spain, Turkey, Pakistan, Sudan, South Africa, and Mexico.

5. A report by the WHO/UNICEF Joint Monitoring Programme for Water Supply and Sanitation (JMP) indicates that a total of 2.5 billion people lacked access to basic toilets and nearly 2,000 children died daily from diarrhea caused by dirty water and poor sanitation (reference?).

6. Some studies in the public health literature examine corporate social responsibility practices that work against the broader public welfare (e.g., Landman, Ling, \& Glantz, 2002).

7. In an economic context of increasing water demand and increasingly scarce water supply, long-term cost recovery may be achieved by transferring at least a portion of the cost of water consumption to domestic and industrial users (Rogers, Bhatia, \& Huber, 1998; Rosegrant, Cai, \& Cline, 2002). The implications on the equity and efficiency goals are twofold: (a) access to water resources by disadvantaged segments of population (or low-income groups) may be reduced and (b) domestic and industrial users may be incentivised to consume less water because they bear the cost of the resources consumed.

8. The Millennium Ecosystem Assessment (2005) builds on ecology-focused frameworks (Convention on Biological Diversity, 2005) to articulate the dominant interpretation of ecosystem services (Milder, Scherr, \& Bracer, 2010; Norgaard, 2010; Pascual, Muradlan, Rodriguez, \& Duralappah, 2010), defining it as including provisioning services such as food and water; regulating services such as regulation of floods, drought, land degradation, and disease; supporting services such as soil formation and 
nutrient cycling; and cultural services such as recreational, spiritual, religious, and other nonmaterial benefit.

9. Virtual water is the volume of water used to produce a commodity or service (Aldaya, Allan, \& Hoekstra, 2010).

10. Aïd et al. (2011) note that water scarcity particularly affects the production of hydropower by releasing water contained in dams through turbines.

11. The water footprint concept was introduced in 2002 as an analogue of the ecological footprint concept originating from the 1990s (Hoekstra, 2009). Water footprint and ecological footprint, according to Hoekstra, should be regarded as complementary in the sustainability debate.

12. Some observers assert that Coca-Cola's bottling operations contributes to the severe water shortages experienced by many communities in India as well as the contamination of groundwater and soil in the region (e.g., Hoffman \& Howie, 2010; Karnani, 2012).

13. Recent research from Mehta, Veldwisch, and Franco (2012) and Sojamo and Larson (2012) elicit concerns that Nestlé's strengthening governance position and bargaining power have resulted in inequities in water allocations at the expense of less powerful (and still voiceless) stakeholders.

14. According to Torraco (2005), the method of "integrative literature review" involves structuring, identifying and synthesising the conceptual content of a specific research field - and therefore guide towards the development of a new framework. A clear and replicable three-step process is followed in this article: (a) defining the unit of analysis, (b) collecting literature data, and (c) classifying/analysing the literature.

15. The Institute for Scientific Information estimates impact based on the absolute number of citations and indirect citation. The impact factor 0.5 was established as indicator of the relative empirical/theoretical quality of the articles reviewed in this study.

16. A staged review was employed to analyse the 603 articles. Following Torraco's (2005) guidelines, I conducted an initial review of abstracts that allowed unveiling the types of tensions that may be associated with corporate water responsibility. I then completed an in-depth review of most relevant articles to understand these tensions and infer plausible solutions and directions for future research.

\section{References}

Aïd, R., Chemla, G., Porchet, A., \& Touzi, N. (2011). Hedging and vertical integration in electricity markets. Management Science, 57, 1438-1452.

Aldaya, M. M., Allan, J. A., \& Hoekstra, A. Y. (2010). Strategic importance of green water in international crop trade. Ecological Economics, 69, 887-894.

Ansink, E., \& Houba, H. (2012). Market power in water markets. Journal of Environmental Economics and Management, 64, 237-252.

Asche, F., Roll, K. H., \& Tveteras, R. (2009). Economic inefficiency and environmental impact: An application to aquaculture production. Journal of Environmental Economics and Management, 58, 93-105.

Balali, M. R., Keulartz, J., \& Korthals, M. (2009). Reflexive water management in arid regions: The case of Iran. Environmental Values, 18, 91-112.

Barberan, R., \& Arbués, F. (2009). Equity in domestic water rates design. Water Resources Management, 23, 2101-2118.

Barton, B. (2010). Murky waters? Corporate reporting on water risk: A benchmarking of 100 companies. Boston, MA: Ceres.

Batjargal, B., Hitt, M., Tsui, A., Arregle, J.-L., Webb, J., \& Miller, T. (2012). Institutional polycentrism, entrepreneurs' social networks and new venture growth. Academy of Management Journal, 56, 10241049.

Bouquet, C., \& Birkinshaw, J. (2008). Managing power in the multinational corporation: How low-power actors gain influence. Journal of Management, 34, 477-508.

Browne, J., \& Nuttall, R. (2013). Beyond corporate social responsibility: Integrated external engagement. Retrieved from http://www.mckinsey.com/insights/strategy/beyond_corporate_social_responsibility_integrated_external_engagement

Bui, L. T. M., \& Kapon, S. (2012). The impact of voluntary programs on polluting behavior: Evidence from pollution prevention programs and toxic releases. Journal of Environmental Economics and Management, 64, 31-44. 
Caplan, D., Dutta, S. K., \& Lawson, R. A. (2013). Corporate social responsibility initiatives across the value chain. Journal of Corporate Accounting \& Finance, 24(3), 15-24.

Cason, T. N., \& Gangadharan, L. (2012). Empowering neighbours versus imposing regulations: An experimental analysis of pollution reduction schemes. Journal of Environmental Economics and Management, $65,469-484$.

Chakraborti, L., \& McConnell, K. E. (2012). Does ambient water quality affect the stringency of regulations? Plant-level evidence of the Clean Water Act. Land Economics, 88, 518-535.

Chalmers, K., Godfrey, J. M., \& Lynch, B. (2012). Regulatory theory insights into the past, present and future of general purpose water accounting standard setting. Accounting, Auditing \& Accountability Journal, 25, 1001-1024.

Chapagain, A. K. and Tickner, D. (2012). Water footprint: help or hindrance? Water Alternatives, 5, 563581.

Chatterji, A. K., \& Toffel, M. W. (2010). How firms respond to being rated. Strategic Management Journal, $31,917-945$

Clarke, R. (2013). Water: The international crisis. New York, NY: Earthscan.

Collins, A. R., \& Maille, P. (2011). Group decision-making theory and behavior under performance-based water quality payments. Ecological Economics, 70, 806-812.

Connor, J. D., Schwabe, K., King, D., \& Knapp, K. (2012). Irrigated agriculture and climate change: The influence of water supply variability and salinity on adaptation. Ecological Economics, 77, 149-157.

Convention on Biological Diversity. (2005). Handbook of the Convention on Biological Diversity including its Cartegena protocol on biosafety (3rd ed.). Montreal, Quebec, Canada: Author.

Cook, B. R., \& Spray, C. J. (2012). Ecosystem services and integrated water resource management: Different paths to the same end? Journal of Environmental Management, 109, 93-100.

Cox, M., \& Ross, J. M. (2011). Robustness and vulnerability of community irrigation systems: The case of the Taos valley acequias. Journal of Environmental Economics and Management, 61, 254-266.

Cuickshank, A., \& Grover, V. I. (2012). A brief introduction to integrated water resources management. In V. I. Grover \& G. Krantzberg (Eds.), Great Lakes: Lessons in participatory governance (pp. 167-183). Boca Raton, FL: CRC Press.

DEFRA. (2011). Europe 2020 Strategy: Roadmap to a resource efficient Europe. Retrieved from http:// www.defra.gov.uk/publications/files/resource-efficient-europe.pdf

Desrochers, P. (2010). The environmental responsibility of business is to increase its profits (by creating value within the bounds of private property rights). Industrial and Corporate Change, 19, 161-204.

de Villiers, C., Naiker, V., \& van Staden, C. J. (2011). The effect of board characteristics on firm environmental performance. Journal of Management, 37, 1636-1663.

Dvarioniene, J., \& Stasiskiene, Z. (2007). Integrated water resource management model for process industry in Lithuania. Journal of Cleaner Production, 15, 950-957.

Espínola-Arredondo, A., \& Muñoz-García, F. (2011). Can incomplete information lead to under-exploitation in the commons? Journal of Environmental Economics and Management, 62, 402-413.

European Union. (2013). Horizon 2020: The framework programme for research and innovation. Brussels, Belgium: European Commission.

Evans, M. F., Gilpatric, S. M., \& Liu, L. (2009). Regulation with direct benefits of information disclosure and imperfect monitoring. Journal of Environmental Economics and Management, 57, 284-292.

Fleurbaey, M., \& Tadenuma, K. (2007). Do irrelevant commodities matter? Econometrica, 75, 1143-1174.

Fooks, G., Gilmore, A., Collin, J., Holden, C., \& Lee, K. (2013). The limits of corporate social responsibility: Techniques of neutralization, stakeholder management and political CSR. Journal of Business Ethics, 112, 283-299.

Gladwin, T., Kennelly, J., \& Krause, T. (1995). Shifting paradigms for sustainable development: Implications for management theory and research. Academy of Management Review, 20, 878-907.

Global Water Partnership. (2000). Integrated water resource management (Technical Advisory Committee Background Paper No. 4). Stockholm, Sweden: Author.

Gond, J.-P., \& Crane, A. (2010). Corporate social performance disoriented: Saving the lost paradigm? Business \& Society, 49, 677-703.

González-Benito, J., \& González-Benito, Ó. (2010). A study of determinant factors of stakeholder environmental pressure perceived by industrial companies. Business Strategy and the Environment, 19, 164-181. doi:10.1002/bse.631 
Gren, I.-M. (2008). Adaptation and mitigation strategies for controlling stochastic water pollution: An application to the Baltic Sea. Ecological Economics, 66, 337-347.

Habisch, A., \& Adaui, C. R. L. (2013). A social capital approach towards social innovation. In T. Osburg \& R. Schmidpeter (Eds.), Social innovation: Solutions for a sustainable future (pp. 65-76). Berlin, Germany: Springer.

Hart, S. L. (1995). A natural resource-based view of the firm. Academy of Management Review, 20, 9861014.

Hess, S., \& Beharry-Borg, N. (2012). Accounting for latent attitudes in willingness-to-pay studies: The case of coastal water quality improvements in Tobago. Environmental \& Resource Economics, 52, 109-131.

Hill, M. (2013). Water governance in the context of IWRM: Chile. In M. Hill (Ed.), Climate change and water governance (Vol. 54, pp. 141-154). Dordrecht, Netherlands: Springer.

Hoekstra, A. Y. (2009). Human appropriation of natural capital: A comparison of ecological footprint and water footprint analysis. Ecological Economics, 68, 1963-1974.

Hoffman, A., \& Howie, S. (2010). Coke in the cross hairs: Water, India, and the University of Michigan. Ann Arbor: GlobaLens, William Davidson Institute at the University of Michigan.

Jones, M. J. (2010). Accounting for the environment: Towards a theoretical perspective for environmental accounting and reporting. Accounting Forum, 34, 123-138.

Kang, J. (2013). The relationship between corporate diversification and corporate social performance. Strategic Management Journal, 34, 94-109.

Karnani, A. (2012). Corporate social responsibility does not avert the tragedy of the commons-Case study: Coca-Cola India. Ann Arbor, MI: Ross School of Business.

Knapp, K. C., \& Schwabe, K. A. (2008). Spatial dynamics of water and nitrogen management in irrigated agriculture. American Journal of Agricultural Economics, 90, 524-539.

Kremer, M., Leino, J., Miguel, E., \& Zwane, A. P. (2011). Spring cleaning: Rural water impacts, valuation, and property rights institutions*. Quarterly Journal of Economics, 126, 145-205.

Kurland, N. B., \& Zell, D. (2010). Water and business: A taxonomy and review of the research. Organization \& Environment, 23, 316-353.

Lambooy, T. (2011). Corporate social responsibility: Sustainable water use. Journal of Cleaner Production, $19,852-866$.

Landman, A., Ling, P. M., \& Glantz, S. A. (2002). Tobacco industry youth smoking prevention programs: Protecting the industry and hurting tobacco control. American Journal of Public Health, 92, 917-930.

Lennox, J., Proctor, W., \& Russell, S. (2011). Structuring stakeholder participation in New Zealand's water resource governance. Ecological Economics, 70, 1381-1394.

Lieberherr, E., Klinke, A., \& Finger, M. (2012). Towards legitimate water governance? The partially privatized Berlin waterworks. Public Management Review, 14, 923-946.

Loch, A. J., Bjornlund, H., Wheeler, S., \& Connor, J. (2012). Allocation trade in Australia: A qualitative understanding of irrigator motives and behaviour. Australian Journal of Agricultural and Resource Economics, 56, 42-60.

Lohmann, L. (2009). Toward a different debate in environmental accounting: The cases of carbon and costbenefit. Accounting, Organizations and Society, 34, 499-534.

Lorenzo-Molo, C. F., \& Udani, Z. A. S. (2013). Bringing back the essence of the "S" and "R" to CSR: Understanding the limitations of the merchant trade and the white man's burden. Journal of Business Ethics, 117, 123-136.

Mariola, M. J. (2011). The commodification of pollution and a preemptive double movement in environmental governance: The case of water quality trading. Organization \& Environment, 24, 231-248.

Marques, R. C., \& De Witte, K. (2011). Is big better? On scale and scope economies in the Portuguese water sector. Economic Modelling, 28, 1009-1016.

Martinez, F. (2012). The syncretism of environmental and social responsibility with business economic performance. Management of Environmental Quality, 23, 597-614.

Martinez, F. (2013). Integrating green into business strategies and operations: Compatibility analysis and syncretistic perspective (Unpublished doctoral dissertation). Cardiff University, Wales.

Mehta, L., Veldwisch, G. J., \& Franco, J. (2012). Introduction to the special issue: Water grabbing? Focus on the (re)appropriation of finite water resources. Water Alternatives, 5, 193-207. 
Merrey, D. J. (2008). Is normative integrated water resources management implementable? Charting a practical course with lessons from Southern Africa. Physics and Chemistry of the Earth, Parts $A / B / C$, 33(8-13), 899-905.

Messerlin, P. A. (2011). Climate, trade and water: A "grand coalition"? The World Economy, 34, 18831910.

Milder, J. C., Scherr, S. J., \& Bracer, C. (2010). Trends and future potential of payment for ecosystem services to alleviate rural poverty in developing countries. Ecology \& Society, 15(2). Retrieved from http://www.ecologyandsociety.org/vol15/iss2/art4/

Millennium Ecosystem Assessment. (2005). Ecosystems and human well-being: Synthesis. Washington, DC: Island Press.

Money, A. (2014). Corporate water risk: A critique of prevailing best practice. Journal of Management and Sustainability, 4, 42-58.

Montiel, I., Husted, B. W., \& Christmann, P. (2012). Using private management standard certification to reduce information asymmetries in corrupt environments. Strategic Management Journal, 33, 11031113.

Morrison, J., Morikawa, M., Murphy, M., \& Schulte, P. (2009). Water scarcity and climate change: Growing risks for business and investors. Boston, MA: Pacific Institute \& Ceres.

Murphy, R. (2004). Disaster of sustainability: The dance of human agents with nature's actants. Canadian Review of Sociology and Anthropology, 41, 249-266.

Nataraj, S., \& Hanemann, W. M. (2011). Does marginal price matter? A regression discontinuity approach to estimating water demand. Journal of Environmental Economics and Management, 61, 198-212.

Norgaard, R. B. (2010). Ecosystem services: From eye-opening metaphor to complexity blinder. Ecological Economics, 69, 1237-1244.

Novo, P., Garrido, A., \& Varela-Ortega, C. (2009). Are virtual water "flows" in Spanish grain trade consistent with relative water scarcity? Ecological Economics, 68, 1454-1464.

OECD. (2012). OECD environmental outlook to 2050: The consequences of inaction. Paris, France: Author. Retrieved from http://www.oecd.org/environment/indicators-modelling-outlooks/oecdenvironmentaloutlookto2050theconsequencesofinaction.htm

Ollivier, H. (2012). Growth, deforestation and the efficiency of the REDD mechanism. Journal of Environmental Economics and Management, 64, 312-327.

Olmstead, S. M. (2010). The economics of managing scarce water resources. Review of Environmental Economics and Policy, 4, 179-198.

Ostrom, E. (2010). Beyond markets and states: Polycentric governance of complex economic systems. American Economic Review, 100, 641-672.

Pache, A.-C., \& Santos, F. (2012). Inside the hybrid organization: Selective coupling as a response to conflicting institutional logics. Academy of Management Journal, 56, 972-1001.

Pahl-Wostl, C., Conca, K., Kramer, A., Maestu, J., \& Schmidt, F. (2013). Missing links in global water governance: A processes-oriented analysis. Ecology \& Society, 18(2). Retrieved from http://www. ecologyandsociety.org/vol18/iss2/art33/

Pahl-Wostl, C., Tàbara, D., Bouwen, R., Craps, M., Dewulf, A., Mostert, E., . . Taillieu, T. (2008). The importance of social learning and culture for sustainable water management. Ecological Economics, 64, 484-495.

Paneque Salgado, P., Corral Quintana, S., Guimarães Pereira, Â., del Moral Ituarte, L., \& Pedregal Mateos, B. (2009). Participative multi-criteria analysis for the evaluation of water governance alternatives. A case in the Costa del Sol (Málaga). Ecological Economics, 68, 990-1005.

Pascual, U., Muradlan, R., Rodriguez, L. C., \& Duralappah, A. (2010). Exploring the links between equity and efficiency in payments for environmental services: A conceptual approach. Ecological Economics, 69, 1237-1244.

Peloza, J. (2009). The challenge of measuring financial impacts from investments in corporate social performance. Journal of Management, 35, 1518-1541.

Pfeiffer, L., \& Lin, C. Y. C. (2012). Groundwater pumping and spatial externalities in agriculture. Journal of Environmental Economics and Management, 64, 16-30.

Porter, M. E., \& Kramer, M. R. (2011). Creating shared value: How to reinvent capitalism—and unleash a wave of innovation and growth. Harvard Business Review, 89(1/2), 62-77.

Postel, S. L. (1992). The last oasis. London, England: Earthscan. 
Rassier, D., \& Earnhart, D. (2010). Does the Porter hypothesis explain expected future financial performance? The effect of clean water regulation on chemical manufacturing firms. Environmental and Resource Economics, 45, 353-377.

Reed, A. M., \& Reed, D. (2009). Partnerships for development: Four models of business involvement. Journal of Business Ethics, 90, 3-37.

Rice, J. (2013). Controlled flooding in the Grand Canyon: Drifting between instrumental and ecological rationality in water management. Organization \& Environment, 26, 412-430.

Ringer, C., Cai, X., \& You, J.-Y. (2008). Substitution between water and other agricultural inputs: Implications for water conservation in a River Basin context. Ecological Economics, 66, 38-50.

Rivera, J. E. (2010). Business and public policy: Responses to environmental and social protection processes. Cambridge, England: Cambridge University Press.

Rogers, P., Bhatia, R., \& Huber, A. (1998). Water as a social and economic good: How to put the principle into practice. Stockholm, Sweden: Global Water Partnership.

Rosegrant, M. W., Cai, X., \& Cline, S. (2002). Global water outlook to 2025: Averting an impending crisis. Washington, DC: International Food Policy Research Institute.

Rueda-Manzanares, A., Aragón-Correa, J. A., \& Sharma, S. (2008). The influence of stakeholders on the environmental strategy of service firms: The moderating effects of complexity, uncertainty and munificence. British Journal of Management, 19, 185-203.

Russo, M. V., \& Fouts, P. A. (1997). A resource-based perspective on corporate environmental performance and profitability. Academy of Management Journal, 40, 534-559.

SABMiller and WWF (2009). Water footrpinting: identifying and addressing water riskes in the value chain. Surrey, UK: SABMiller and WWF-UK.

Schaefer, A. (2007). Contrasting institutional and performance accounts of environmental management systems: Three case studies in the UK water \& sewerage industry. Journal of Management Studies, 44, 506-535.

Schaible, G. D., Kim, C. S., \& Aillery, M. P. (2010). Dynamic adjustment of irrigation technology/water management in western U.S. agriculture: Toward a sustainable future. Canadian Journal of Agricultural Economics, 58, 433-461.

Scodanibbio, L. (2011). Opening a policy window for organisational change and full-cost accounting: The creation of BC Hydro's water use planning program. Ecological Economics, 70, 1006-1015.

Simpson, D., Power, D., \& Klassen, R. (2012). When one size does not fit all: A problem of fit rather than failure for voluntary management standards. Journal of Business Ethics, 110, 85-95.

Smith, E. G., Eiswerth, M. E., \& Veeman, T. S. (2010). Current and emerging water issues in agriculture: An overview. Canadian Journal of Agricultural Economics, 58, 403-409.

Sojamo, S., \& Larson, E. A. (2012). Investigating food and agribusiness corporations as global water security, management and governance agents: The case of Nestlé, Bunge and Cargill. Water Alternatives, 5, 619-635.

Spash, C. L., Urama, K., Burton, R., Kenyon, W., Shannon, P., \& Hill, G. (2009). Motives behind willingness to pay for improving biodiversity in a water ecosystem: Economics, ethics and social psychology. Ecological Economics, 68, 955-964.

Starik, M., \& Kanashiro, P. (2013). Toward a theory of sustainability management: Uncovering and integrating the nearly obvious. Organization \& Environment, 26, 7-30. doi:10.1177/1086026612474958

Stern, N. (2008). The economics of climate change. American Economic Review, 98(2), 1-37.

Sun, W., \& Cui, K. (2014). Linking corporate social responsibility to firm default risk. European Management Journal, 32, 275-287.

Swanson, D. L. (1999). Toward an integrative theory of business and society: A research strategy for corporate social performance. Academy of Management Review, 24, 506-521.

The Coca-Cola Company and The Nature Conservancy (2010). Producr water footprinting assessemnts: practical application in corporate water stewardship. TCCC and TNC.

Torraco, R. J. (2005). Writing integrative literature reviews: Guidelines and examples. Human Resource Development Review, 4, 356-367.

UNICEF and World Health Organization (2008). Progress on drinking water and sanitation: special focus on sanitation. United States of America: UNICEF \& WHO.

United Nations Development Programme. (2006). Human development report. New York, NY: Author. 
United Nations Water \& Food and Agriculture Organization of the United Nations. (2007). Coping with water scarcity: Challenge of the twenty-first century. New York, NY: Author.

UN Water. (2012). The 4th United Nations World Water Development Report: Managing water under uncertainty and risk (Vol. 1). Paris, France: UNESCO.

Utting, P., \& Zammit, A. (2009). United Nations business partnerships: Good intentions and contradictory agendas. Journal of Business Ethics, 90, 39-56.

Valente, M. (2010). Demystifying the struggle of private sector paradigmatic change: Business as an agent in a complex adaptive system. Business \& Society, 49(3), 439-476.

Valente, M. (2012). Theorizing firm adoption of sustaincentrism. Organization Studies, 33, 563-591.

Van den Brink, R., Van der Laan, G., \& Moes, N. (2012). Fair agreements for sharing international rivers with multiple springs and externalities. Journal of Environmental Economics and Management, 63, 388-403.

van Oel, P. R., Mekonnen, M. M., \& Hoekstra, A. Y. (2009). The external water footprint of the Netherlands: Geographically-explicit quantification and impact assessment. Ecological Economics, 69, 82-92.

Visser, W. (2014). CSR 2.0: Transforming corporate sustainability and responsibility. Berlin, Germany: Springer

Volk, M., Hirschfeld, J., Dehnhardt, A., Schmidt, G., Bohn, C., Liersch, S., \& Gassman, P. W. (2008). Integrated ecological-economic modelling of water pollution abatement management options in the Upper Ems River Basin. Ecological Economics, 66, 66-76.

Water Resources Group. (2013). Expanding our horizon: Water security partnerships for people, growth, and the environment-2030 WRG annual report. Washington, DC: Author.

Whiteman, G., Walker, B., \& Perego, P. (2013). Planetary boundaries: Ecological foundations for corporate sustainability. Journal of Management Studies, 50, 307-336.

Willmott, H. (2012). Reframing relevance as "social usefulness": A comment on Hodgkinson and Starkey's "Not Simply Returning to the Same Answer Over and Over Again." British Journal of Management, 23, 598-604.

Wissenburg, M. (2013). What is water? The history of a modern abstraction. Environmental Politics, 22, 356-358.

Wolf, J. (2011). Sustainable supply chain management integration: A qualitative analysis of the German manufacturing industry. Journal of Business Ethics, 102, 221-235.

World Business Council for Sustainable Development. (2013). Vision 2050: The new agenda for business. Paris, France: Author.

Worldwide Fund for Nature. (2012). Living planet report 2012: Biodiversity, biocapacity and better choices. London, England: Author.

Wu, Z., \& Pagell, M. (2011). Balancing priorities: Decision-making in sustainable supply chain management. Journal of Operations Management, 29, 577-590.

Zhang, Z., Yang, H., \& Shi, M. (2011). Analyses of water footprint of Beijing in an interregional inputoutput framework. Ecological Economics, 70, 2494-2502.

\section{Author Biography}

Fabien Martinez is Marie Sklodowska Curie postdoctoral research fellow at the Academy of Business in Society (Brussels). 